\title{
Aero - surveillance of Various Units in a Quaternary Care Hospital Based on Seasonal Perspective - An Observational Study
}

\author{
G. Lokeshwari ${ }^{1}$, G. Balajee ${ }^{1}$ and T. Premalatha ${ }^{2^{*}}$ \\ ${ }^{1}$ Department of Microbiology, ${ }^{2}$ Department of Biostatistics, Gleneagles Global Health City, \\ No. 439, Cheran Nagar, Perumbakkam, Chennai, Tamil Nadu 600100 \\ *Corresponding author
}

\section{A B S T R A C T}

K e y w o r d s
Hospital air
sampling, Seasonal
bio-burden,
Surveillance,
Microbial count,
Hospital air quality,
Aspergillus
Article Info
Accepted:
17 August 2020
Available Online:
10 September 2020

Hospital indoor air and surfaces are good sources of bacteria, viruses and fungi which can lead to Hospital acquired infections (HAI) in susceptible hosts. Effective environmental disinfection and HVAC system maintenance are vital in preventing HAI. This study was aimed at estimating baseline data of bacterial and fungal bio burden during different seasons in a year and to strengthen infection control practices as there was an external construction work behind our hospital. A retrospective analysis of air surveillance data over a period of one year from July 2015 to June 2016 at a quaternary care hospital was done. Sampling was done with air petri sampler to check the quality of indoor and outdoor air once a month at 21 fixed locations. Nutrient agar plates (NA) and Sabouraud's Chloramphenicol agar (SCA) plates were used. Bacteria and fungi suspended in air impinge on the agar surface. NA and SCA plates were incubated at $37^{\circ} \mathrm{C}, 48$ hours and $25^{\circ} \mathrm{C}, 7$ days respectively. Number of $\mathrm{CFU} / \mathrm{m}^{3}$ calculated based on the air sampler manufacturer's instructions. Average bacterial $\mathrm{CFU} / \mathrm{m}^{3}$ in operation theatres and ICU was 29.65 and 93.85 respectively and that of fungi was 2.27 and 3.27 respectively. The maximum bacterial load was in summer and maximum fungal load was in south west monsoon. Aspergillus spp. was found throughout the year. Yeast and dematiaceous fungi like Curvularia spp., Alternaria spp. and Cladophialophora spp. were mostly found indoor during monsoons.

\section{Introduction}

The probability of an infection is directly proportional to the dose of microorganism, receptive host site of contact, time of contact and the virulence of the microorganism. It is inversely proportional to the host defenses attempting to prevent infection. Environment is the background where the agent - host interaction occurs. Environmental factors include physical factors, biological factors and social factors ${ }^{1}$.
Hospital is an important indoor environment responsible for spread of airborne pathogens. The incidence of airborne infections has increased in recent years. The reason is increase in hospitals with sealed and selfcontained circulating air systems for temperature control ${ }^{2}$. Increase in immune compromised patients also contributes to higher incidence in hospital acquired fungal and opportunistic bacterial infections. 
Bacteria, viruses, yeast and fungal spores are suspended in air either as small individual particles or larger clumps and aggregates. They can settle and serve as an important source of infection in patients or health care workers ${ }^{1}$. Sources of microbes in the hospital are categorized into environment, healthcare workers and patients. The microbes in the environment is influenced by construction in and around hospital, during dusting activities, pillows, curtains, changes in the air currents while opening and closing the doors. The clothes, desquamated skin, hair particles, shoes, exhaled air, flatulence of the healthcare workers and patients, droplet or airborne infections from the infected patients also contribute to the microbes in the hospital environment ${ }^{3}$.

Microbiological air sampling is done to determine the number and types of microorganisms in indoor air. The indoor air quality is affected by various factors which include indoor traffic, visitors, temperature, time of the day, season, relative humidity, relative concentration of microorganisms, performance of air handling system components.

This study is focused on the influence of physical factor such as seasons on the quality of air and quantity of bioaerosols in various locations inside the hospital and outdoor air.

\section{Objectives}

\section{Primary objectives}

To study the microbiological quality of hospital indoor and outdoor air using air sampler.

To quantitative and study the distribution of various bacteria and fungi in the air during different seasons of the year.

\section{Secondary objectives}

To develop reasonable interventions to prevent Hospital Acquired Infections.

Study design: Retrospective observational study

\section{Materials and Methods}

A retrospective analysis of air surveillance data over a period of one year from July 2015 to June 2016 at a quaternary care hospital was done.

Air sampling to check the quality of indoor and outdoor air was done every third week of the month at 21 fixed locations.

\section{Inclusion criteria}

Indoor: Operation theatres, Intensive Care Units (ICU), Isolation rooms, Emergency room, Special General ward, OPD treatment room.

Outdoor: IP-OP open passage.

\section{Exclusion criteria}

Outdoor air of the area behind the IP block due to nearby Construction outside the hospital campus.

\section{Sampling locations}

One outdoor and twenty indoor locations were sampled.

The indoor locations sampled in the ground floor were ground floor operation theatre 1 (GOT-1), Emergency room(ER), Special General ward 2 (SGW2), Orthopaedic outpatient treatment room (Ortho OP $\mathrm{T}_{\mathrm{x}}$ room). The indoor locations sampled in the first floor were first floor operation theatres 1 
and 4(OT1, OT4), Bone Marrow transplant unit(BMT), Bone Marrow transplant unit isolation room 1(BMT Iso 1), Liver transplant ICU(LICU), Liver transplant ICU isolation room 3(LICU Iso 3), Liver Medical ICU(LMICU), Liver Medical ICU isolation room 1(LMICU Iso 1), Cardio-Thoracic ICU(CT ICU), Cardio-Thoracic ICU isolation room 2 (CT ICU Iso 2), Medical ICU(MICU), Surgical ICU(SICU), Neurology ICU(NICU), Cardiac Critical care Unit(CCU), Paediatric ICU(PICU), Paediatric ICU isolation room 1(PICU Iso 1). The outdoor location sampled was open passage between inpatient and outpatient blocks (IP- OP open passage).

The locations under study were categorized into 8 categories as follows:

OT1, OT4, BMT, BMT ISO 1 as category 1; GOT1 as category 2; ER, SGW2, ORTHO $\mathrm{T}_{\mathrm{x}}$ room as category 3; MICU, PICU, SICU, NICU, LMICU, CCU as category 4, CTICU ISO 2, LICU Iso 3, LMICU Iso 1 as category 5; PICU Iso 1 as category 6; LICU, CTICU as category 7 , IP-OP passage as category 8 .

The Bacterial and fungal load in various locations were compared with four seasons in a year namely Southwest monsoon, Northeast monsoon, Winter, Hot weather.

\section{As} www.tn.gov.in/deptst/climateandrainfall.pdf, during the study year, Southwest monsoon was from June to September, Northeast monsoon was from October to December, winter was from January to February and Hot weather was from March to May ${ }^{4}$.

\section{Air sampling Procedure}

A microbial air sampler (Himedia LA474 Air sampler) was used for sampling of airborne bacteria and fungi ${ }^{5}$. This air sampling system is based on the principle of sieve impactor, which aspirates air through a perforated plate. The resulting air-stream is directed onto the agar surface of a standard Petri dish. The Petri dish is then incubated and the colonies counted. It is designed to precipitate contaminant carrying particle practically having cut-off size $d_{50}<3 \mu \mathrm{m}^{5}$.

The air sampler was operated at an air flowrate of $100 \mathrm{~L} / \mathrm{min}$. The sampling time was 5 min to avoid drying of the agar surface and overloading of the collection plate ${ }^{6}$. The total volume of air aspirated onto an agar plate was $500 \mathrm{~L}$ in each sample ${ }^{5}$. The air sampler was set up at a height of one meter above the floor level. The air sampler lid was autoclaved before starting procedure for the day and cleaned with $70 \%$ ethanol between sampling of various locations ${ }^{7}$.

\section{Culture media and microbial identification}

Nutrient agar (NA) was used for sampling and cultivation of bacteria. Nutrient agar plates were incubated at $37^{\circ} \mathrm{C}$ for 48 hours to allow the growth of aerobic bacteria. Bacterial colonies were characterized by conventional methods.

For isolation of fungi, Sabouraud's dextrose agar supplemented with $10 \quad \mathrm{mg} / \mathrm{L}$ chloramphenicol (SCA) was used. SCA plates were incubated for 7 days at $25^{\circ} \mathrm{C}$ to allow the growth of fungal colonies. A wet mount preparation of each fungal colony was prepared by using lacto phenol-cotton-blue solution and examined microscopically. Identification of fungi was based on macroscopic and microscopic morphology.

\section{Statistical analysis}

The number of colony forming units (CFU) on the agar plate (r) was counted. The bacterial colonies were enumerated at 48 hours of incubation. The fungal colonies were 
enumerated at 7 days of incubation. $P_{r}$, the most probable no. of microorganisms in the volume of air sampled for the no. of CFU (r) was obtained from the Feller's table for positive hole correction. The $\mathrm{CFU} / \mathrm{m}^{3}$ was calculated by the formula ${ }^{5}$ :

$$
\mathrm{CFU} / \mathrm{m}^{3}=\frac{\mathrm{P}_{\mathrm{r}} \text { value }}{0.5}
$$

Statistical analyses were performed using Epi Info 7, a tool for public health physicians as well as researchers. Bacterial and fungal colony units were expressed in mean \pm S.D. Statistical differences between the groups were analysed using Kruskalwallis test for both fungal and bacterial CFU. p value less than 0.05 was considered statistically significant.

\section{Results and Discussion}

In this study, the air quality was studied in various fixed locations during third week of every month over a period of one year. The observations were as follows:

The average bacterial and fungal $\mathrm{CFU} / \mathrm{m}^{3}$ in the air of sampled locations during different seasons of the year is given in table 1 and table 2, respectively. There was a difference in the bacterial $\mathrm{CFU} / \mathrm{m}^{3}$ during various seasons of the year and between locations which was statistically significant $(\mathrm{p}<0.001)$. Also, there was a difference in the fungal $\mathrm{CFU} / \mathrm{m}^{3}$ during various seasons of the year and it was statistically significant $(\mathrm{p}<0.001)$. The average bacterial $\mathrm{CFU} / \mathrm{m}^{3}$ in the sterile areas like OT and BMT was $30 \mathrm{CFU} / \mathrm{m}^{3}$, Isolation rooms was $48 \mathrm{CFU} / \mathrm{m}^{3}$ and ICUs was $94 \mathrm{CFU} / \mathrm{m}^{3}$. The average fungal $\mathrm{CFU} / \mathrm{m}^{3}$ in the sterile areas like OT and BMT was 2 $\mathrm{CFU} / \mathrm{m}^{3}$, Isolation rooms was $2 \mathrm{CFU} / \mathrm{m}^{3}$ and ICUs was $3 \mathrm{CFU} / \mathrm{m}^{3}$. The Bacterial load was maximum during hot weather season of the year (March to May) in both outdoor and indoor air. Coagulase-Negative Staphylococcus, Micrococcus and Aerobic spore forming bacilli were the common bacterial isolates. The fungal load was found maximum during South-West monsoon season (June to September). Figure 1 represents the mean indoor fungal species and their $\mathrm{CFU} / \mathrm{m}^{3}$ during different seasons of the year. Aspergillus spp. was the commonest fungi observed throughout the year. Dematiaceous fungi like Curvularia spp., Cladophialophora bantiana and Alternaria spp. were found in indoor air during monsoons.

Microbiologic sampling of the environment has shifted from regularly scheduled cultures of air and environmental surfaces to targeted sampling for defined purpose since 1970 as per Centre for Disease Control (CDC) and American Hospital Association (AHA) ${ }^{1,8}$. Microbiologic sampling of air, water and inanimate surfaces is an expensive and time consuming process. It is indicated for the following four situations: outbreak investigation of an infectious disease, research purposes, to monitor potential hazardous bioterrorism agent and for quality assurance to evaluate any change in infection prevention and control practices ${ }^{1}$.

During this study year, there was a huge construction going on behind the hospital campus. Infection Control Risk Assessment (ICRA) guidelines were strictly adhered to prevent any adverse outcomes ${ }^{9}$.

This study was planned to detect any break in infection control measures. Since the physical factors such as the temperature, humidity, outdoor air quality varies in different geographical areas, it is better to have an idea on the baseline values of bacterial and fungal colony forming units of the hospital by performing air sampling over a period of time. Any significant increase in the number 
of microorganism or a new isolate shall be an alert to tighten strict infection control practices.

Various air sampling methods available for enumerating airborne microorganisms are impingement in liquids, impaction on solid surfaces (sieve or slit design), sedimentation, filtration, centrifugation, electrostatic precipitation and thermal precipitation. Of these, impaction on solid surfaces, filtration and centrifugation methods can be used for enumerating both bacterial and fungal bioaerosols. Sedimentation method (settle plate) is not recommended for air sampling of fungal spores because the fungal spores can remain suspended in air indefinitely ${ }^{1}$.

\section{Air borne bacterial counts}

Acceptable Bacterial counts while sampling air with Himedia LA474 Air sampler is as follows ${ }^{5}$ : OT for most of the surgeries should have colony counts $<353 \mathrm{CFU} / \mathrm{m}^{3}$. OT where Central Nervous System surgeries are done should have colony counts $<35.3$ $\mathrm{CFU} / \mathrm{m}^{3}$. There is no defined data for other areas of the hospital.

Verification and validation of environmental quality in surgical areas -SEGLA, Spain has defined the following criteria for assessing indoor air quality in hospital environments ${ }^{10}$.

\begin{tabular}{|l|l|}
\hline $\mathbf{C F U} / \mathbf{m 3}$ & Indoor air Quality \\
\hline $\mathbf{1 0}$ & Very Clean \\
\hline $\mathbf{1 0}-\mathbf{1 0 0}$ & Clean \\
\hline $\mathbf{1 0 0}-\mathbf{2 0 0}$ & Acceptable \\
\hline $\mathbf{2 0 0}$ & Contaminated \\
\hline
\end{tabular}

The air samples in this study were taken during the routine daily work hours in the corresponding areas. The mean bacterial colony count in the sterile areas like Operation theatre was $30 \mathrm{CFU} / \mathrm{m}^{3}$. Bone Marrow Transplant units had Bacterial load less than $10 \mathrm{CFU} / \mathrm{m}^{3}$ with no fungal colonies throughout the year. The Isolation rooms where transplant patients were kept in the immediate post operative period had a mean of $48 \mathrm{CFU} / \mathrm{m}^{3}$ with the exception of PICU which had $151 \mathrm{CFU} / \mathrm{m}^{3}$. The ICUs had a mean of $94 \mathrm{CFU} / \mathrm{m}^{3}$. The Emergency room, General ward and orthopedic treatment room had a mean bacterial count of $110 \mathrm{CFU} / \mathrm{m}^{3}$. During the same period the mean outdoor bacterial count was $667 \mathrm{CFU} / \mathrm{m}^{3}$. In our study, commonest bacterial isolates observed were Coagulase-Negative Staphylococcus, Micrococcus and Aerobic spore forming bacilli.

The samples from the cleanest environment should have the lowest numbers when compared to the clean areas of the hospital ${ }^{1}$. This is true and statistically significant with the above data except in PICU. There was an increase in the number of bacteria in the months of September and April in PICU. Appropriate measures like cleaning of the Air Handling Unit, air flow ducts and filters were done. Also strict infection control practices and restriction of visitors were insisted.

The Bacterial CFUs varied from $5 \mathrm{CFU} / \mathrm{m}^{3}$ to $75 \mathrm{CFU} / \mathrm{m}^{3}$ in Operation theatres in the studies reviewed ${ }^{11,12,13,14,15,16}$. The Bacterial CFUs varied from 4 to $135 \mathrm{CFU} / \mathrm{m}^{3}$ in ICUs in various studies where the methodology was active air surveillance ${ }^{11,12,13,14,15,16}$.

\section{Staphylococcus spp., Micrococcus spp., Streptococcus spp., Enterococcus spp., Bacillus subtilis, Escherichia coli, Enterobacter spp., Proteus spp., Pseudomonas spp. were the common bacterial isolates in the hospital indoor air in various studies $^{11,12,13,14,15,16,17}$.}

The Health care associated infection caused by bacteria is multi-factorial. It depends on the adequacy of hand hygiene by the 
Healthcare workers, patients, patient care takers and visitors, personal hygiene of the patients and visitors, the extent to which we focus on cleaning of inanimate environmental surfaces with appropriate disinfectant for recommended contact time rather than the airborne bioaerosols per se.

\section{Air borne fungal levels}

More than two colonies may represent a point source within the patient care environment. Repeat sampling is recommended to determine if it was a passing phenomenon. Pathogen content should be $<1 \mathrm{CFU} / \mathrm{m}^{3}$ with repeat sampling ${ }^{1}$.

The fungal spores resist drying and can be carried over considerable distances via air and remain viable. They can also settle on surfaces and become airborne during sweeping or bed making. Thus, possibility of outdoor fungi causing infection should also be considered.

In this study, the Sabouraud's dextrose agar supplemented with $10 \mathrm{mg} / \mathrm{L}$ Chloramphenicol (SCA) plates used for fungal culture were incubated at $25^{\circ} \mathrm{C}$, as the study was aimed at to have a check on ventilation. The samples incubated at room temperature are intended to demonstrate ventilation deficiencies where as the sample incubated at $37^{\circ} \mathrm{C}$ is to detect pathogens 1 .

The mean fungal colony count in the sterile areas like Operation theatre and Bone Marrow Transplant units, Isolation rooms was 2 $\mathrm{CFU} / \mathrm{m}^{3}$, ICUs was $3 \mathrm{CFU} / \mathrm{m}^{3}$, Emergency room, General ward and orthopedic treatment room was $5 \mathrm{CFU} / \mathrm{m}^{3}$. Air monitoring throughout the year predicted an increase in counts during south west monsoon especially in July. The high count in category 1 during Southwest monsoon was due to Candida tropicalis in OT1. Deep cleaning and fogging of OT1 was done immediately. Follow up cultures were within limits. Also, an increase in fungal CFU was found in other units of the hospital during Southwest monsoon. Cleaning of Air Handling Unit, air flow ducts and filters were done. Housekeeping was strengthened to keep the surfaces clean and dry to prevent airborne fungal infections in vulnerable patients.

Of the fungi isolated throughout the year, Aspergillus spp. was observed in our air samples throughout the year and in particular was found more in number during hot weather season. Candida spp., Dematiaceous fungi, Mycelia sterilia predominates during the monsoon seasons (Figure 1). This is in concordance with the study conducted at Chandigarh by Rudramurthy et al., (2016) in which Aspergillus spp. was the most common genera isolated throughout the year except in the months of April and October in Airconditioned areas where black fungi were isolated $^{18}$.

\section{Outdoor Vs Indoor fungus ratio (Fig 2 - 5)}

Indoor to outdoor fungal colony count should be less than one [Indoor: Outdoor (I:O) $<1$ Colony] except after rain. If the ratio is more than one, an internal source may be suspected $^{1}$.

\section{Indoor: Outdoor ratio less than one}

In this study, Aspergillus flavus, Aspergillus niger during all seasons, Fusarium spp. and Rhizopus arhizus during south west monsoon; Curvularia spp. in North East monsoon; Rhizopus arhizus during winter; Cunninghamella spp. and Mycelia sterilia during hot weather were found more in the outdoor environment, thus $\mathrm{I}: \mathrm{O}<1$. Mycelia sterilia include fungal colonies that have not developed reproductive structures and subsequently not identified by morphological characteristics. 
Literature review on aero-mycological study in various geographical locations

\begin{tabular}{|c|c|c|c|c|}
\hline S.no. & $\begin{array}{l}\text { Study- author, year and } \\
\text { place }\end{array}$ & Fungal CFU $/ \mathbf{m}^{3}$ & Fungal Genera & $\begin{array}{l}\text { Seasonal variation - peak } \\
\text { period }\end{array}$ \\
\hline 1. & $\begin{array}{l}\text { Alka Singh et al., 1994, } \\
\text { Delhi, } \\
\text { India }^{19}\end{array}$ & $53 \mathrm{CFU} / \mathrm{m}^{3}$ & $\begin{array}{l}\text { Cladosporium spp., Aspergillus } \\
\text { flavus, Aspergillus niger, } \\
\text { Aspergillus versicolor, } \\
\text { Fusarium spp., } \\
\text { Alternaria spp.,Penicillium } \\
\text { citrinum, and Penicillium } \\
\text { oxalicum }\end{array}$ & June - September \\
\hline 2. & $\begin{array}{l}\text { Santra et al., } 1989, \\
\text { Calcutta, India }\end{array}$ & - & $\begin{array}{l}\text { Aspergillus, Alternaria, } \\
\text { Curvularia, Penicillium, } \\
\text { Rliizopus, Cladosporium and } \\
\text { Candida }\end{array}$ & Post - Monsoon period \\
\hline 3. & $\begin{array}{l}\text { Rudramurthy et al., 2016, } \\
\text { Chandigarh, India }{ }^{18}\end{array}$ & $\begin{array}{l}82 \mathrm{CFU} / \mathrm{m}^{3}(\mathrm{AC}) \\
\text { and } \\
122 \mathrm{CFU} / \mathrm{m}^{3} \\
(\text { Non-AC) }\end{array}$ & $\begin{array}{l}\text { Aspergillus flavus, Aspergillus } \\
\text { fumigatus, Aspergillus niger, } \\
\text { Penicillium spp., Rhizopus } \\
\text { arrhizus, Rhizopus microsporus, } \\
\text { Alternaria alternata, Curvularia } \\
\text { lunata, Fonsecaea pedrosoi, } \\
\text { Bipolaris hawaiiensis, Fusarium } \\
\text { solani, Fusarium oxysporum, } \\
\text { Acremonium spp., Candida } \\
\text { albicans, Candida tropicalis, } \\
\text { Geotrichum, Trichosporon spp., } \\
\text { and some unidentified fungi }\end{array}$ & No significant seasonal variation \\
\hline 4. & $\begin{array}{l}\text { Kishor Kumar et al., } \\
\text { Mysuru, } 2018 \text { India }^{11}\end{array}$ & $\begin{array}{l}18 \mathrm{CFU} / \mathrm{m}^{3} \text { to } \\
48 \mathrm{CFU} / \mathrm{m}^{3}\end{array}$ & $\begin{array}{l}\text { Aspergillus spp., Penicillum spp. } \\
\text { and Candida spp. }\end{array}$ & - \\
\hline 5. & $\begin{array}{l}\text { Premina } \\
\text { Sivagnanasundaram et al., } \\
\text { 2019, Srilanka }{ }^{13}\end{array}$ & - & $\begin{array}{l}\text { Fusarium spp, and Aspergillus } \\
\text { spp. }\end{array}$ & - \\
\hline 6. & $\begin{array}{l}\text { Agbagwa et al., 2014, } \\
\text { Nigeria }^{14}\end{array}$ & $5-180 \mathrm{CFU} / \mathrm{m}^{3}$ & $\begin{array}{l}\text { Aspergillus spp, } \\
\text { Mucor spp, and Candida spp. }\end{array}$ & - \\
\hline 7. & $\begin{array}{l}\text { Qudiesat et al., 2009, } \\
\text { Jordan }^{15}\end{array}$ & $\begin{array}{l}2 \mathrm{CFU} / \mathrm{m}^{3} \text { in } \\
\text { Operation room } \\
\text { of private hospital } \\
\text { to } 73 \mathrm{CFU} / \mathrm{m}^{3} \text { in } \\
\text { outdoor air of } \\
\text { Government } \\
\text { hospital }\end{array}$ & $\begin{array}{l}\text { Aspergillus spp., Penicillium } \\
\text { spp., Rhizopus spp. and } \\
\text { Alternaria spp. }\end{array}$ & - \\
\hline 8. & 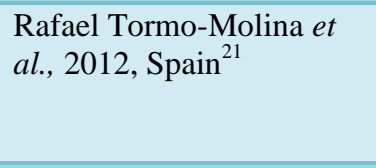 & $\begin{array}{l}107 \mathrm{CFU} / \mathrm{m}^{3} \\
\text { outdoors and } 24 \\
\mathrm{CFU} / \mathrm{m}^{3} \text { indoors }\end{array}$ & $\begin{array}{l}\text { Cladosporium spp., yeasts, } \\
\text { Alternaria spp., Penicillium spp., } \\
\text { Aspergillus spp both indoor and } \\
\text { outdoor environment }\end{array}$ & $\begin{array}{l}\text { Outdoor Fungal peak in summer } \\
\text { and indoor peak in spring and } \\
\text { autumn. }\end{array}$ \\
\hline 9. & $\begin{array}{l}\text { José Manuel Ríos-Yuil et } \\
\text { al., 2012, Mexico }^{22}\end{array}$ & $\begin{array}{l}85.08 \pm 29.19 \\
\mathrm{CFU} / \mathrm{m} 3 \text { in ICU } \\
\text { of a General } \\
\text { hospital }\end{array}$ & $\begin{array}{l}\text { Cladosporium spp., Penicillium } \\
\text { spp., Aspergillus spp. (non- } \\
\text { fumigatus), Fusarium spp., } \\
\text { Exophialaspp., Syncephalastrum } \\
\text { spp., and Acremonium spp. }\end{array}$ & - \\
\hline 10. & $\begin{array}{l}\text { Lathika Bhatia et al.,2010, } \\
\text { Madhyapradesh, India }{ }^{16}\end{array}$ & $\begin{array}{l}0.12 \times 10^{2} \text { to } \\
1 \times 10^{2} \mathrm{CFU} / \mathrm{m}^{3}\end{array}$ & $\begin{array}{l}\text { Aspergillus spp., Fusarium spp, } \\
\text { Mucor spp, Penicillum spp. } \\
\text { Verticillium spp, Rhizopus } \\
\text { spp.and Candida spp. }\end{array}$ & - \\
\hline
\end{tabular}


Table.1 Season-wise mean bacterial bio-burden during the year 2015 - 2016

\begin{tabular}{|c|c|c|c|c|c|c|}
\hline Locations & Category & $\begin{array}{l}\text { Southwest } \\
\text { monsoon } \\
\left(\mathrm{CFU} / \mathbf{m}^{3}\right)\end{array}$ & $\begin{array}{l}\text { Northeast } \\
\text { Monsoon } \\
\left(\text { CFU/m }{ }^{3}\right)\end{array}$ & $\begin{array}{l}\text { Winter } \\
\left(\text { CFU/m }{ }^{3}\right)\end{array}$ & $\begin{array}{l}\text { Hot weather } \\
\left(\text { CFU/m }{ }^{3}\right)\end{array}$ & $\begin{array}{c}\text { Mean } \pm \text { S.D } \\
\left(\text { CFU/m }{ }^{3}\right)\end{array}$ \\
\hline $\begin{array}{l}\text { OT1, OT4, } \\
\text { BMT, } \\
\text { BMT ISO } 1\end{array}$ & 1 & 31.75 & 21.67 & 23.5 & 41.41 & $29.65 \pm 94.04$ \\
\hline GOT1 & 2 & 33.5 & 2.67 & 4 & 57.33 & $24.5+26.23$ \\
\hline $\begin{array}{l}\text { ER, SGW2, } \\
\text { ORTHO T } \\
\text { room }\end{array}$ & 3 & 120 & 71.76 & 96.44 & 152 & $110.05 \pm 34.20$ \\
\hline $\begin{array}{l}\text { PICU, SICU, } \\
\text { NICU, } \\
\text { LMICU, } \\
\text { CCU,MICU }\end{array}$ & 4 & 119.78 & 61.55 & 72 & 122.08 & $93.85 \pm 31.57$ \\
\hline $\begin{array}{l}\text { CTICU ISO 2, } \\
\text { LICU Iso 3, } \\
\text { LMICU Iso } 1\end{array}$ & 5 & 55.5 & 33.75 & 36.33 & 68 & $48.52 \pm 16.3$ \\
\hline PICU Iso 1 & 6 & 209 & 30 & 45 & 320 & $151 \pm 138.8$ \\
\hline LICU, CTICU & 7 & 125.75 & 50.66 & 55.5 & 152 & $96.04 \pm 50.76$ \\
\hline $\begin{array}{l}\text { IP-OP open } \\
\text { passage }\end{array}$ & 8 & 480 & 649.42 & 741.33 & 799 & $667.44 \pm 139.31$ \\
\hline $\begin{array}{l}\text { Mean } \pm \text { S.D } \\
\left(\text { CFU } / \mathbf{m}^{3}\right)\end{array}$ & & $99.33 \pm 63.76$ & $38.86 \pm 23.96$ & $47.53 \pm 30.71$ & $130.40 \pm 94.95$ & - \\
\hline
\end{tabular}

$\mathrm{CFU} / \mathrm{m}^{3}$ - Colony forming unit per metre cube; S.D - Standard Deviation; OT1 - Operation theatre 1; BMT Bone Marrow transplant unit; BMT ISO 1 - Bone Marrow transplant unit isolation 1; OT4operation theatre 4; GOT 1- Ground floor operation theatre 1; ER - Emergency room; SGW2 - Special General ward 2; ORTHO $\mathrm{T}_{\mathrm{x}}$ room - Orthopaedic outpatient treatment room; MICU - Medical ICU; PICU - Paediatric ICU; SICU - Surgical ICU; NICU - Neurology ICU; LMICU - Liver Medical ICU; CCU Cardiac Critical care Unit; CTICU ISO 2 - Cardio-Thoracic ICU isolation room 2; LICU Iso 3 - Liver transplant ICU isolation room 3; LMICU Iso 1- Liver Medical ICU isolation room 1; PICU Iso 1 Paediatric ICU isolation room 1; LICU - Liver transplant ICU; CTICU - Cardio-Thoracic ICU; IP-OP open passage - open passage between inpatient and outpatient blocks.

Kruskal Wallis test $\mathrm{p}<0.001$ considered highly statistically significant. Since our data didn't meet linearity, we performed Kruskalwallis test to find whether a difference exists between the groups. Bacterial $\mathrm{CFU} / \mathrm{m}^{3}$ was significantly different with respect to seasons $\mathrm{H}=16.424, \mathrm{p}=0.001$ 
Table.2 Season-wise mean fungal bio-burden during the year 2015 - 2016

\begin{tabular}{|c|c|c|c|c|c|c|}
\hline Locations & Category & $\begin{array}{c}\text { Southwest } \\
\text { monsoon } \\
\left(\mathrm{CFU} / \mathbf{m}^{3}\right)\end{array}$ & $\begin{array}{l}\text { Northeast } \\
\text { Monsoon } \\
\left(\text { CFU/m }{ }^{3}\right)\end{array}$ & $\begin{array}{c}\text { Winter } \\
(\text { CFU/m³ }\end{array}$ & $\begin{array}{l}\text { Hot weather } \\
(\text { CFU/m³) }\end{array}$ & $\begin{array}{c}\text { Mean } \\
\left(\mathrm{CFU} / \mathrm{m}^{3}\right)\end{array}$ \\
\hline $\begin{array}{l}\text { OT1, OT4, BMT, BMT } \\
\text { ISO } 1\end{array}$ & 1 & 7.25 & 0.53 & 0 & 1.33 & 2.27 \\
\hline GOT1 & 2 & 3.5 & 0 & 0 & 3 & 1.62 \\
\hline $\begin{array}{l}\text { ER, SGW2, } \\
\text { ORTHO T } \text { Trom }_{x} \text { rool }\end{array}$ & 3 & 7.66 & 4.88 & 3 & 3.33 & 4.71 \\
\hline $\begin{array}{l}\text { MICU, PICU, SICU, } \\
\text { NICU, LMICU, CCU }\end{array}$ & 4 & 2.6 & 1.2 & 2.3 & 1 & 2.62 \\
\hline $\begin{array}{l}\text { CTICU ISO 2, } \\
\text { LICU Iso 3, LMICU Iso } 1\end{array}$ & 5 & 5 & 0 & 3 & 1.83 & 2.45 \\
\hline PICU Iso 1 & 6 & 6 & 2 & 2 & 2.66 & 3.16 \\
\hline LICU, CTICU & 7 & 7.25 & 1 & 1.5 & 3.33 & 3.27 \\
\hline IP-OP passage & 8 & 73.5 & 40 & 17 & 18.66 & 37.29 \\
\hline Mean \pm S.D $\left(\mathrm{CFU} / \mathrm{m}^{3}\right)$ & & $6.09 \pm 1.47$ & $1.37 \pm 1.7$ & $1.68 \pm 1.26$ & $2.35 \pm 0.96$ & - \\
\hline
\end{tabular}

Kruskal wallis test $\mathrm{p}<0.001$ considered highly statistically significant. Since our data didn’t meet linearity, we performed Kruskalwallis test to find whether a difference exists between the groups. Fungal $\mathrm{CFU} / \mathrm{m}^{3}$ was significantly different with respect to seasons. Test statistics $\mathrm{H}=9.6, \mathrm{p}=0.02$

Figure.1

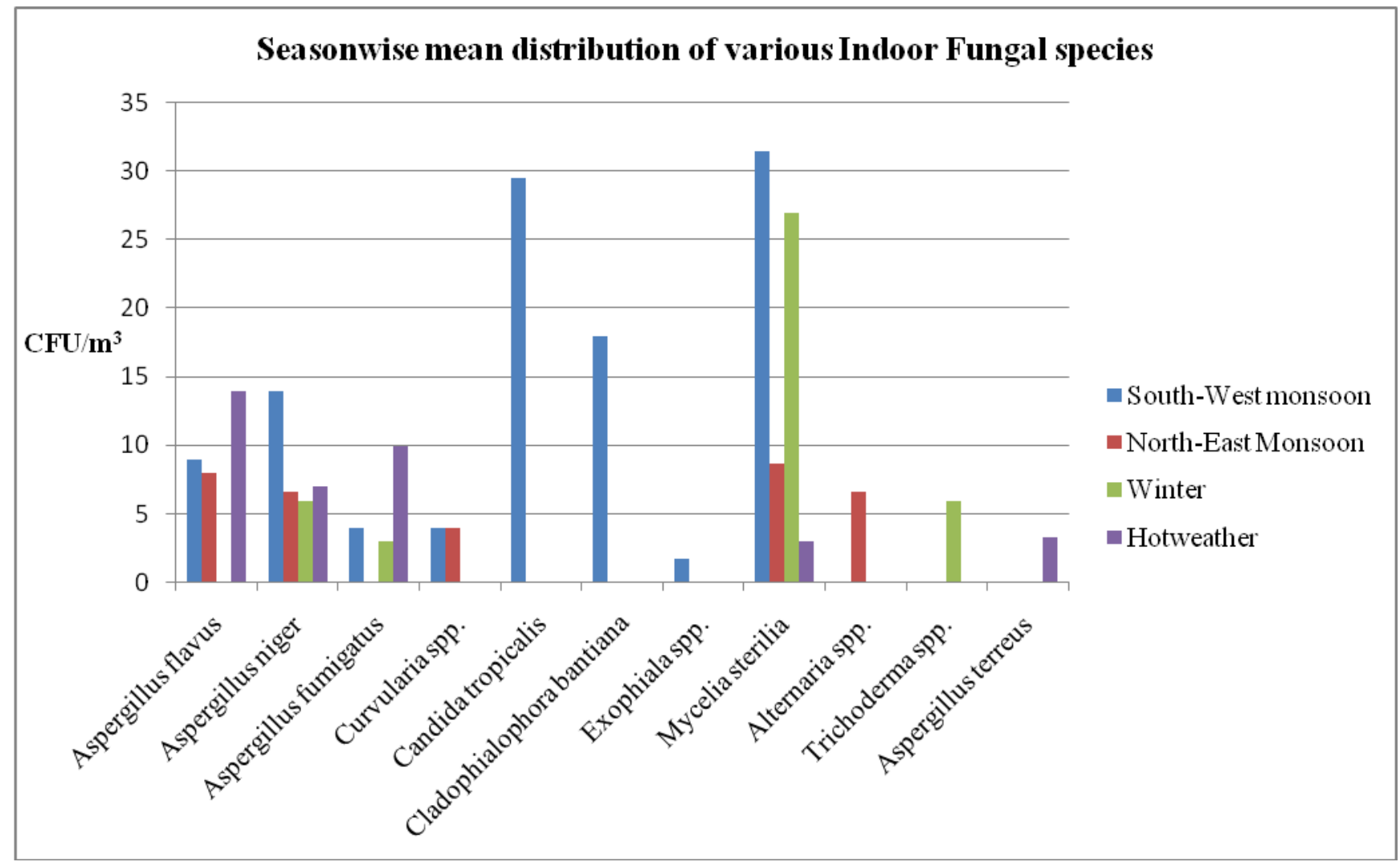


Figure.2

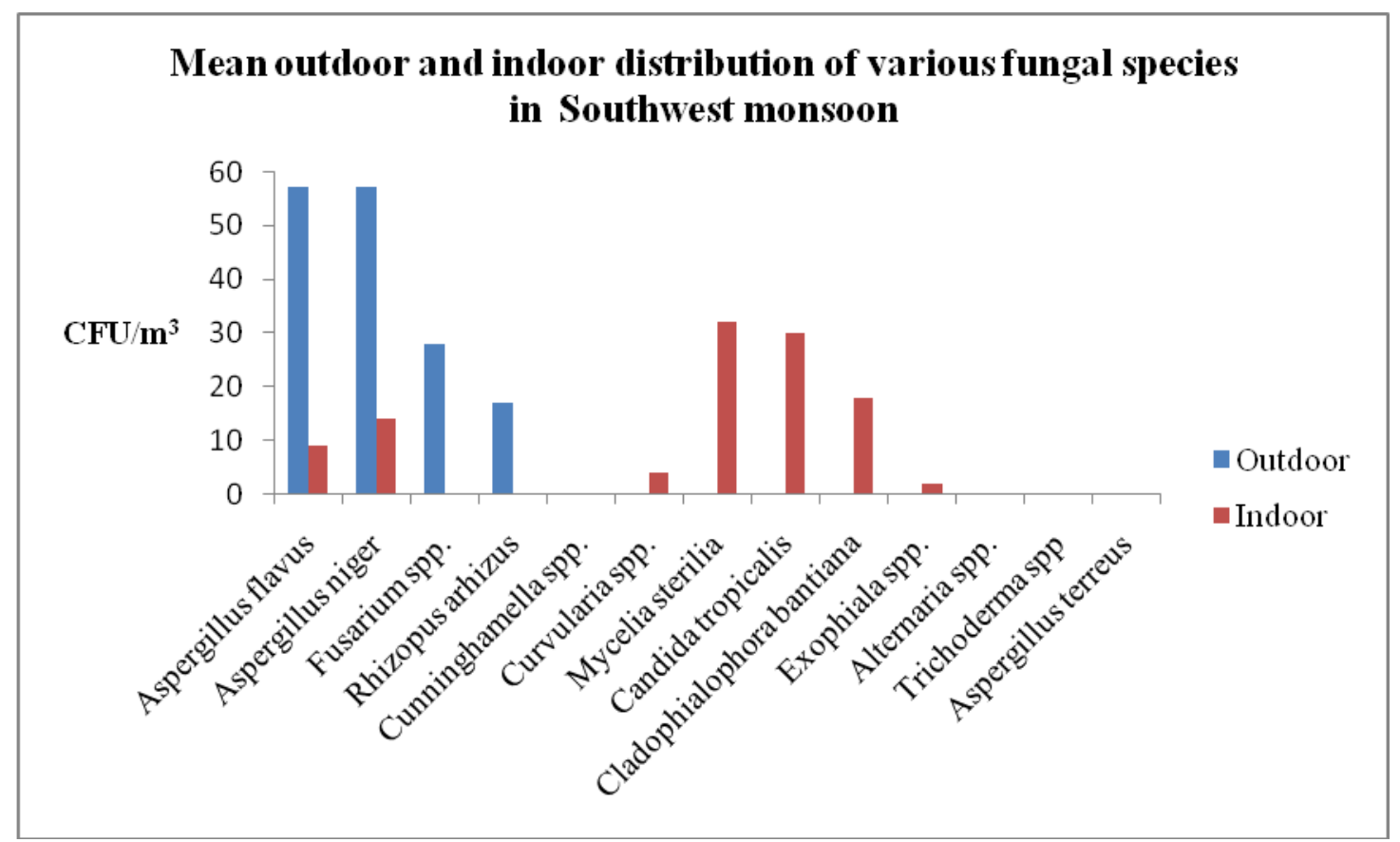

Figure.3

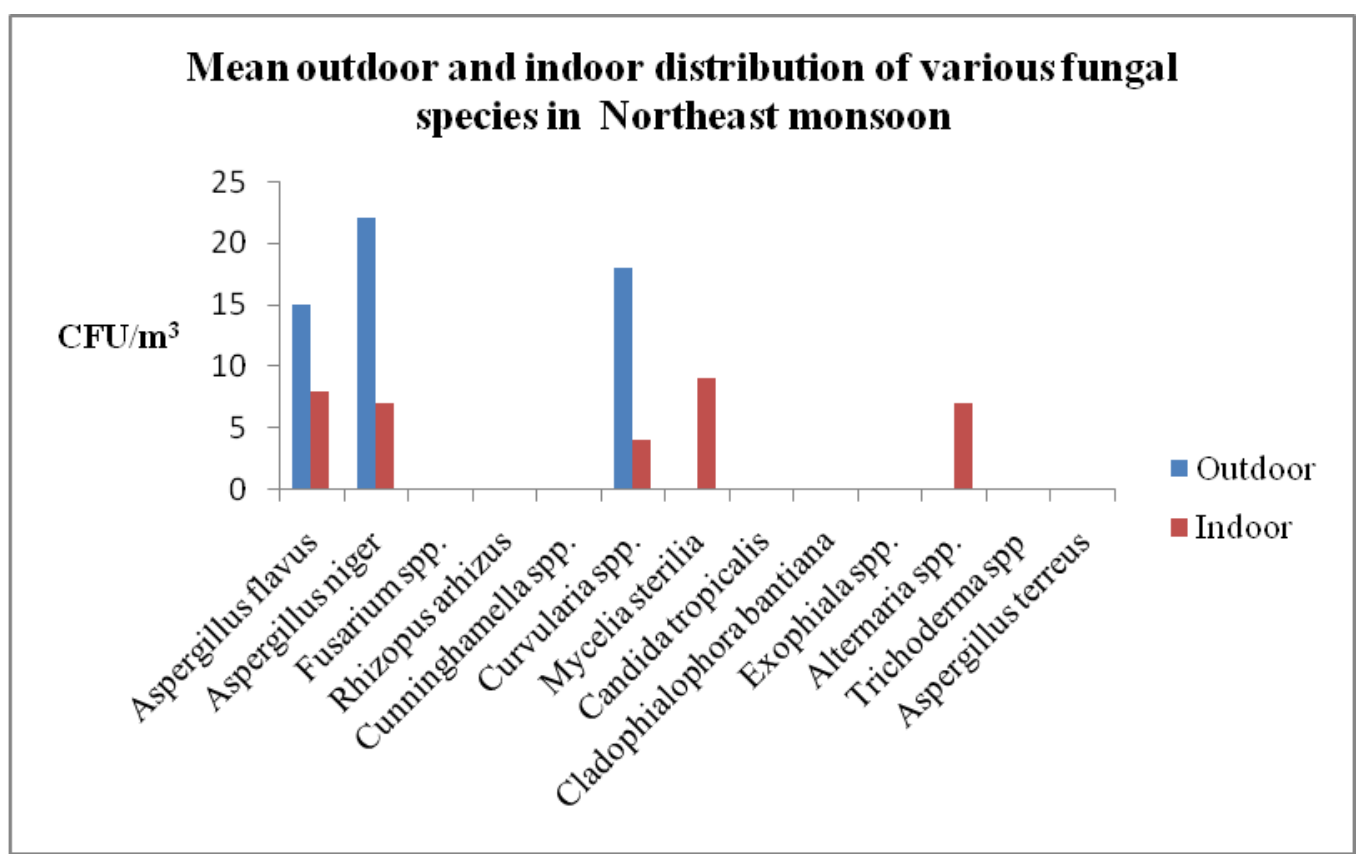


Figure.4

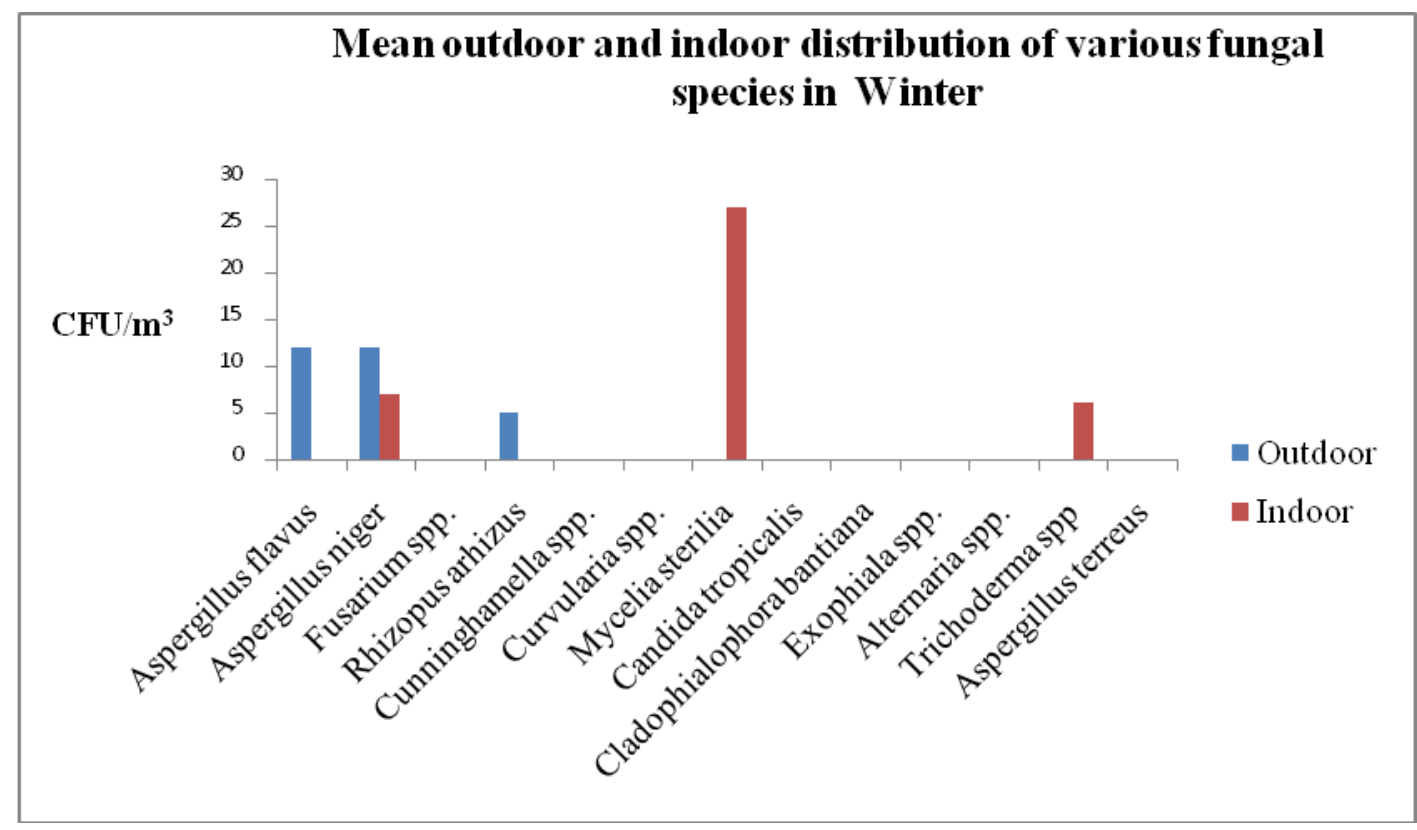

Figure.5

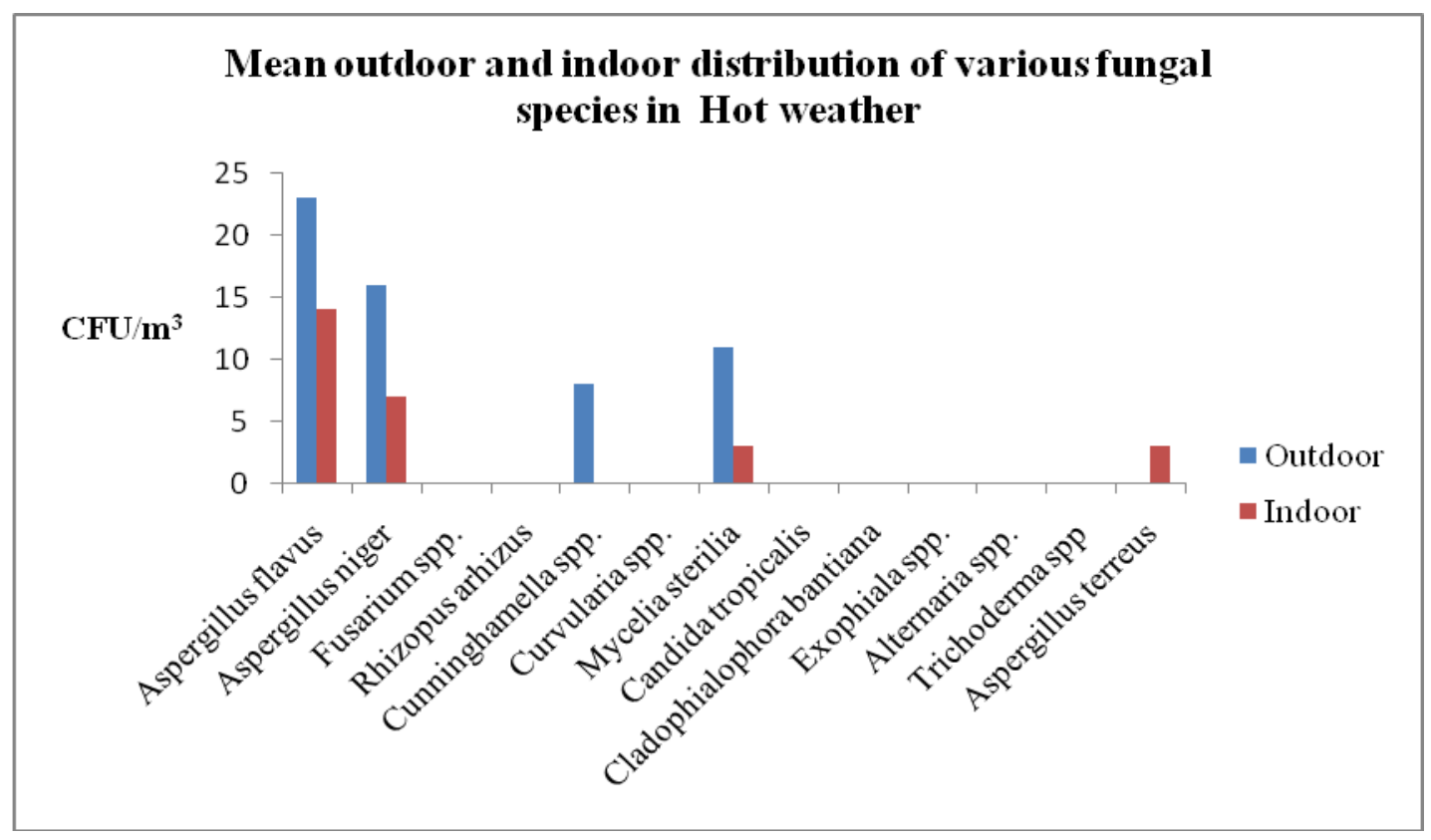

Indoor: Outdoor ratio more than one

Curvularia spp., Candida tropicalis, Cladophialophora bantiana, Exophiala spp. in South West monsoon; Alternaria spp. during North East monsoon; Trichoderma spp. in winter; Aspergillus terreus in hot weather season and Mycelia sterilia during all seasons except hot weather were found more in the indoor environment, thus $\mathrm{I}: \mathrm{O}>1$.

Increase in the indoor fungal CFU during monsoons especially that of dematiaceous molds was due to increase in moisture content 
in the false ceilings following frequent switching off of the air condition system; mud and sand carried in the foot wares following a rain when the roads are bad with rain and drain water stagnation.

\section{Fungal CFU and fungal infection}

In a study on Aspergillus species in transplant areas in Colombia, the average Aspergillus in air was $2.8 \mathrm{CFU} / \mathrm{l}$ and with this Aspergillus load, none of their patients had a fungal infection during the study period. Aspergillus flavus, Aspergillus niger, Aspergillus terreus and Aspergillus versicolor were the isolates in this study ${ }^{23}$. According to Arnow et al., the infection rate was $1.2 \%$ with Aspergillus flavus and Aspergillus fumigatus at 2.2 and $1.1 \mathrm{CFU} / \mathrm{m}^{3}$ respectively ${ }^{24}$. Incidence of fungal infection in solid organ transplant recipients is less than $5 \%$ when compared to HSCT recipients $(5 \%)^{8}$.

In the present study, Aspergillus flavus, Aspergillus niger and Cladophialophora bantiana were the isolates observed in solid organ transplant ICUs and the average Fungal $\mathrm{CFU} / \mathrm{m}^{3}$ was 3. There were no clinical isolates in transplant patients during their stay in ICUs in the study period thus, explaining the adequacy of the infection control practices.

The individuals at high risk of fungal infections are Hematopoietic stem cell transplant recipients (HSCT), patients on chemotherapy, solid organ transplant recipients, preterm neonates and those with other immune compromised states ${ }^{8}$.

\section{High risk environment for Aspergillus and Infection prevention /control methods}

Improperly functioning ventilation systems, air filters, air filter frames, window air conditioners, backflow of contaminated air, air exhaust contamination, false ceilings, damp wood building materials, internal and external constructions, opening doors to construction site and ornamental plants are high risk areas for fungi especially Aspergillus ${ }^{8}$.

Thus, an appropriate airflow, sufficient air exchanges and appropriate filtration are essential for good maintenance of HVAC system. The recommended measurements for special ventilation rooms which includes Positive air pressure, air changes per hour (20 for OT and >12 for Protected environment), sealed room, directed air flow from clean to dirty, HEPA filter $99.97 \%$ efficient at $0.3 \mu \mathrm{m}$ diameter particle at the point of use should be followed to prevent airborne fungal infections in the healthcare setting ${ }^{8}$.

An effective and periodic maintenance of HVAC system is critical especially in a quaternary care hospital where Liver, Renal, Heart, Lung and Bone marrow transplants are being carried out. These individuals are immune compromised and more vulnerable to fungal infections especially to Aspergillus and Mucorales.

\section{Limitations}

Indoor air traffic, number of visitors, time of the day, temperature and humidity were not taken into consideration in comparing the hospital environmental bio-burden.

The bacterial and fungal bio-burden during North-East monsoon is expected to be higher than that in this study: As we encountered the Chennai floods during North-East monsoon (in the year 2015), we were able to do air sampling only after complete cleaning and fogging activities. A very effective and extraordinary cleaning and disinfection practice is exhibited by the well controlled bio-burden during this period of study.

The sampling was done only once a month in fixed locations. If it is done on a daily basis 
including all locations, it will be of help in comparing the influence of environmental isolates in causing clinical infections.

In conclusion the bacterial and fungal average values $\left(\mathrm{CFU} / \mathrm{m}^{3}\right)$ can be used as baseline data to evaluate any spikes at a given location or season. In this study, during summer - hot and dry air showed an increase in bacterial bioburden. During southwest monsoon - damp air, wet and moist indoor environment had comparatively shown an increase in fungal bio-burden. Aspergillus spp. was observed throughout the year. Yeast and dematiaceous fungi like Curvularia spp., Alternaria spp. and Cladophialophora spp. were more commonly found indoor during monsoon season. Bacterial bio-burden in a hospital, even though dynamic, can be averaged based on seasonal estimations which may serve as baseline data for making administrative decisions to enhance Infection Prevention and Control activities of any hospital setting.

\section{Acknowledgement}

Authors thank to $\mathrm{Mr}$ Venkatnarayanan and Ms Pushparani.

\section{Financial support \& sponsorship: Nil}

Conflicts of interest: There is no conflict of interest

Abbreviations: HVAC system - Heat Ventilation Air Condition system; HAI Hospital Acquired Infection; NA - Nutrient Agar; SCA - Sabouraud's Dextrose Agar supplemented with $10 \mathrm{mg} / \mathrm{L}$ chloramphenicol.

\section{References}

1. Hospital epidemiology and infection control, C Glen Mayhall, fourth edition, Lippincott Williams and/Wilkins publications, 2012.

2. Jeffrey Philip Obbard, Airborne concentrations of bacteria in a hospital environment in Singapore, water, air, and soil pollution, 2003, 144: 333-341.

3. Robert J. Sherertz et al., Cloud" HealthCare Workers, Emerging Infectious Diseases, Vol. 7, No. 2, March-April 2001.

4. www.tn.gov.in/deptst/climateanrainfall.p df.tin

5. Air Sampling system, Technical Bulletin, LA474, Himedia.

6. Stetzenbach LD, Buttner MP, Cruz P. (2004). Detection and enumeration of airborne biocontaminants. Current Opin. Biotechnol.15:170-174.

7. Pei-Chih $\mathrm{Wu}$, Huey-Jen Jenny $\mathrm{Su}$ and Hsiao-Man Ho, A Comparison of sampling media for environmental viable fungi collected in a hospital environment. Environ. Res., 2000, Section A 82:253-2.

8. Guidelines for Environmental Infection Control in Health-Care Facilities. Recommendations of CDC and the Healthcare Infection Control Practices Advisory Committee (HICPAC) U.S. Department of Health and Human Services, Centers for Disease Control and Prevention (CDC) Atlanta, GA 30329, 2003, Updated: July 2019 https://www.cdc.gov/infectioncontrol/gui delines/environmental/index.html

9. Best practices in Infection Prevention and Control, An International Perspective, Barbara M. Soule, Prof. Ziad A. Memish, Preeti N. Malani, First Indian Edition, 2013.

10. Cruceta Gloria. Verificación y validación de la calidad ambiental en áreas quirúrgicas. SEGLA, España. 2007.

11. Kishor Kumar $\mathrm{S}$ et al., Comparative Study Of Microbiological Air Quality Of Private And Government Hospitals In Mysuru City, International Journal Of Engineering Sciences \& Research Technology, 7(12): December, 2018

12. Desai $\mathrm{S} \mathrm{N}$ et al., Microbiological 
Surveillance of Operation Theaters \& Intensive Care Units of Teaching Hospital in Surendranagar, Gujarat, Gujarat Medical Journal, August 2012 Vol.67 No.2.

13. Premina Sivagnanasundaram et al., Assessment of Airborne Bacterial and Fungal Communities in Selected Areas of Teaching Hospital, Kandy, Sri Lanka, BioMed Research International, Volume 2019.

14. Agbagwa et al., Microbiological quality of indoor air of a general hospital and a health center in Rivers State Nigeria, Int.J.Curr.Microbiol.App.Sci (2014) 3(12): 424-431.

15. Qudiesat, K, et al. 2009. Assessment of airborne pathogens in healthcare settings, African Journal of Microbiology Research Vol. 3 (2) pp. 066-076.

16. Lathika Bhatia et al., Hospital indoor airborne microflora in private and Government owned hospitals in Sagar City, India, World Journal of Medical Sciences 5(3), 65:70, 2010.

17. Xunliang Tong et al., High diversity of airborne fungi in the hospital environment as revealed by metasequencing based microbiome analysis, Scientific Reports.7:39606, 03 January 2017.

18. Rudramurthy. S. M. 2016. High fungal spore burden with predominance of Aspergillus in hospital air of a tertiary care hospital in Chandigarh, Indian Journal of Medical Microbiology, (2016) 34(4): 529-532.

19. Alka Singh et al., Airborne fungi in the hospitals of metropolitan Delhi, Aerobiologia, $\quad$ volume 10, pages1121(1994)

20. Santra, S. C. 1989. Airborne Fungal Flora in Indoor Environments of the Calcutta Metropolis, India, Grana 28: 141-145, 1989.

21. Rafael Tormo-Molinaa et al., Monitoring the occurrence of indoor fungi in a hospital, Rev Iberoam Micol. 2012; 29(4): 227-234.

22. José Manuel Ríos-Yuil et al., Aeromycological study at the intensive care unit of the Dr. Manuel Gea Gonzalez General Hospital, The Brazilian Journal of Infectious Diseases, 2012; 16(5):432435.

23. Cárdenas, M. X et al., Aspergillus spp. in risk areas of transplant patients in a university hospital, Rev Iberoam Micol, 2008 Dec 31; 25(4):232-6.

24. Arnow PM et al., Endemic and epidemic aspergillosis associated with in-hospital replication of Aspergillus organisms, J Infect Dis. 1991 Nov; 164(5): 998-1002.

\section{How to cite this article:}

Lokeshwari, G., G. Balajee and Premalatha, T. 2020. Aero - surveillance of Various Units in a Quaternary Care Hospital Based on Seasonal Perspective - An Observational Study. Int.J.Curr.Microbiol.App.Sci. 9(09): 2376-2389. doi: https://doi.org/10.20546/ijcmas.2020.909.297 